U.S. DEPARTMENT OF THE INTERIOR

U.S. GEOLOGICAL SURVEY

\title{
Observed and Predicted Pier Scour in Maine
}

Water-Resources Investigations Report 02-4229

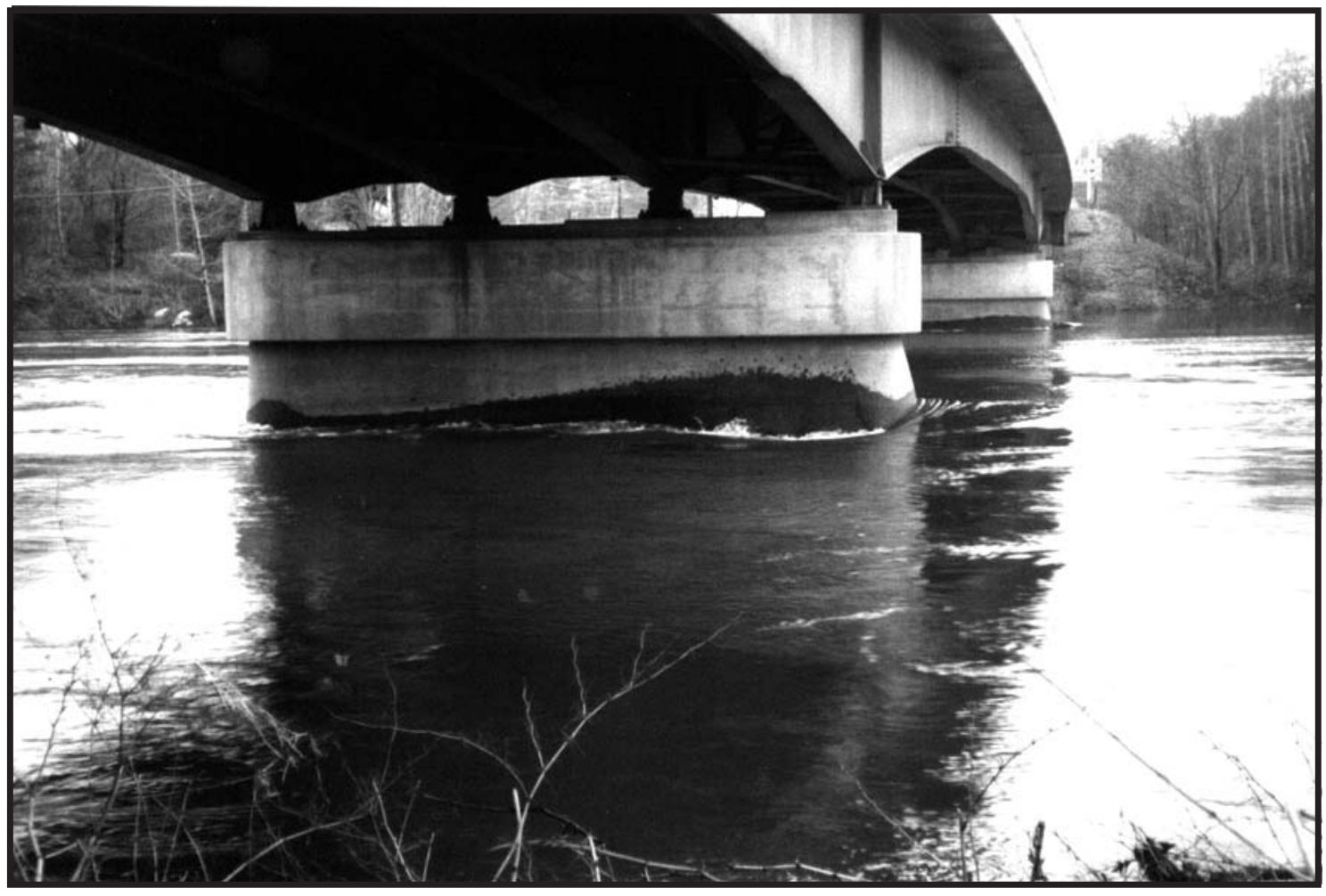

Prepared in cooperation with the

MAINE DEPARTMENT OF TRANSPORTATION

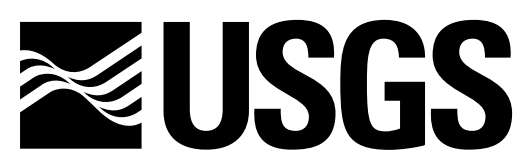

science for a changing world 
Cover Photograph. River flow near bridge piers on Androscoggin River at Bethel, Maine, April 1, 1998. 


\section{Observed and Predicted Pier Scour in Maine}

By Glenn Hodgkins and Pamela Lombard

\section{U.S. GEOLOGICAL SURVEY}

Water-Resources Investigations Report 02-4229

In cooperation with the

MAINE DEPARTMENT OF TRANSPORTATION 


\section{U.S. DEPARTMENT OF THE INTERIOR \\ GALE A. NORTON, Secretary}

U.S. GEOLOGICAL SURVEY

Charles G. Groat, Director

The use of firm, trade, and brand names in this report is for identification purposes

only and does not constitute endorsement by the U.S. Government.

For additional information write to:

District Chief

U.S. Geological Survey

196 Whitten Road

Augusta, ME 04330

http://me.water.usgs.gov
Copies of this report can be purchased from:

U.S. Geological Survey

Branch of Information Services

Box 25286

Federal Center

Denver, CO 80225 


\section{CONTENTS}

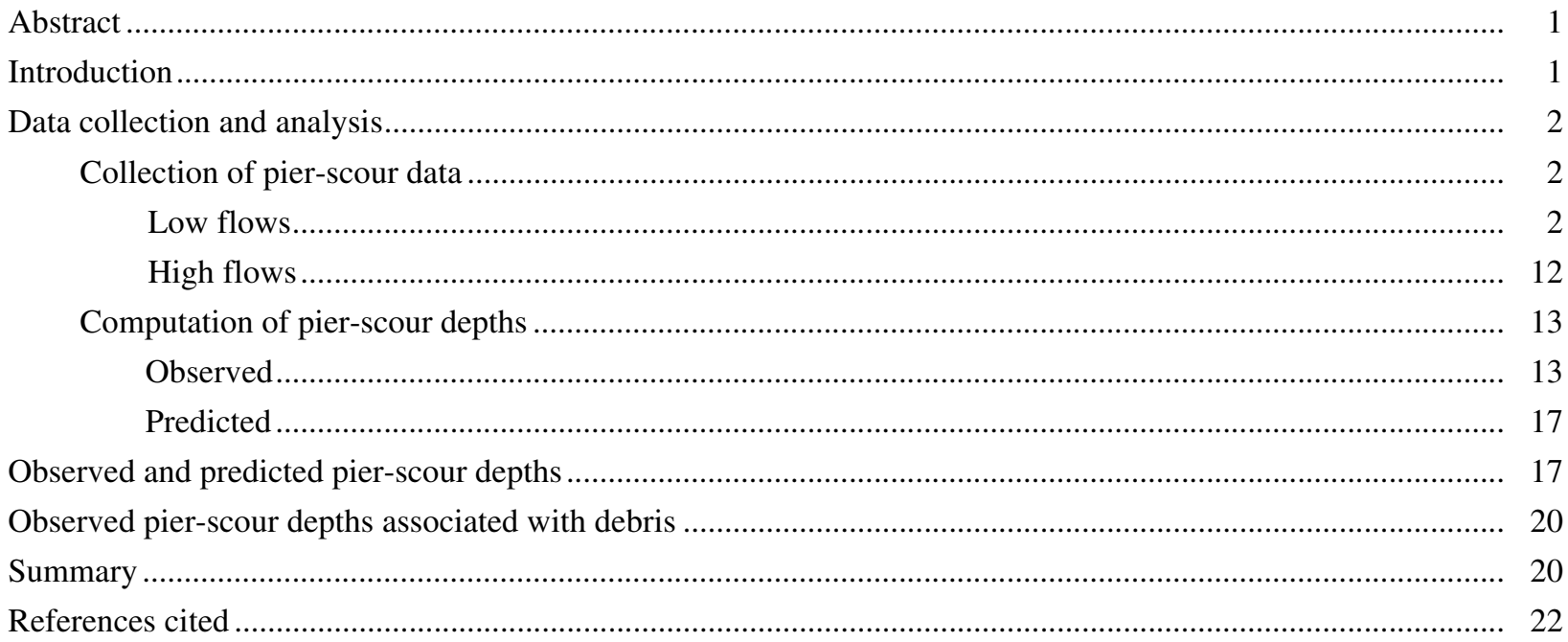

\section{LIST OF FIGURES}

1. Map showing location of bridges with high-flow pier-scour measurements from this study ........................ 3

2. Equipment used for measuring water depth at Saco River at Hiram, Maine, April 22, 1997 ...................... 14

3. River flow near bridge piers on Androscoggin River at Bethel, Maine, April 1, 1998_............................... 15

4. Flow turbulence at the upstream nose of the right (looking downstream) bridge pier

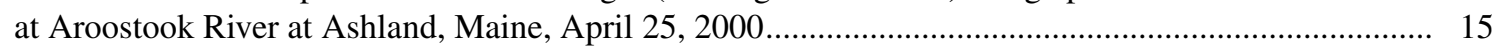

5. Fathometer record of bridge pier-scour hole at the 2nd pier from left (looking downstream) bank at St. John River at Van Buren, Maine, September 3, 1998 ...................................................... 16

6. Observed and predicted maximum pier-scour depths ............................................................................ 21

7. Woody debris accumulation on upstream nose of left (looking downstream) bridge pier at Austin Stream at Bingham, Maine, June 28, 2000.

\section{LIST OF TABLES}

1. Pier-scour information for Kenduskeag River at Bangor, Maine …..................................................... 4

2. Pier-scour information for Kennebec River at Gardiner, Maine............................................................. 5

3. Pier-scour information for Androscoggin River at Bethel, Maine ......................................................... 6

4. Pier-scour information for Penobscot River at Lincoln, Maine................................................................. 7

5. Pier-scour information for Aroostook River at Ashland, Maine ……...................................................... 8

6. Pier-scour information for St. John River at Van Buren, Maine.............................................................. 9

7. Pier-scour information for Austin Stream at Bingham, Maine.......................................................... 10

8. Pier-scour information for Saco River at Hiram, Maine ….............................................................. 11

9. Range of selected pier-scour data from 23 piers in Maine during high flows........................................ 18

10. Predicted and observed maximum pier-scour depths from 23 piers in Maine during high flows ............... 19 
CONVERSION FACTORS, VERTICAL DATUM, AND ABBREVIATIONS

\begin{tabular}{lll}
\hline \multicolumn{1}{c}{ Multiply } & \multicolumn{1}{c}{ By } & \multicolumn{1}{c}{ To obtain } \\
\hline inch (in.) & 25.4 & millimeter \\
foot (ft) & 0.3048 & meter \\
foot per second (ft/s) & 0.3048 & meter per second \\
cubic foot per second $\left(\mathrm{ft}^{3} / \mathrm{s}\right)$ & 0.02832 & cubic meter per second \\
pound (lb) & 0.4536 & kilogram \\
millimeter $(\mathrm{mm})$ & 0.03937 & inch \\
\hline
\end{tabular}

Temperature in degrees Celsius $\left({ }^{\circ} \mathrm{C}\right)$ may be converted to temperature in degrees Fahrenheit $\left({ }^{\circ} \mathrm{F}\right)$ as follows:

$$
{ }^{\circ} \mathrm{F}=\left(1.8 \times{ }^{\circ} \mathrm{C}\right)+32
$$




\title{
Observed and Predicted Pier Scour in Maine
}

\author{
by Glenn Hodgkins and Pamela Lombard
}

\section{ABSTRACT}

Pier-scour and related data were collected and analyzed for nine high river flows at eight bridges across Maine from 1997 through 2001. Six bridges had multiple piers. Fifteen of 23 piers where data were measured during a high flow had observed maximum scour depths ranging from 0.5 feet $(\mathrm{ft})$ to $12.0 \mathrm{ft}$. No pier scour was observed at the remaining eight piers. The maximum predicted pier-scour depths associated with the 23 piers were computed using the equations in the Federal Highway Administration's Hydraulic Engineering Circular number 18 (HEC-18), with data collected for this study. The predicted HEC-18 maximum pier-scour depths were compared to the observed maximum pier-scour depths. The HEC-18 pierscour equations are intended to be envelope equations, ideally never underpredicting scour depths and not appreciably overpredicting them. The HEC-18 pier-scour equations performed well for rivers in Maine. Twenty-two out of 23 pier-scour depths were overpredicted by $0.7 \mathrm{ft}$ to $18.3 \mathrm{ft}$. One pier-scour depth was underpredicted by $4.5 \mathrm{ft}$. For one pier at each of two bridges, large amounts of debris lodged on the piers after high-flow measurements were made at those sites. The scour associated with the debris increased the maximum pier-scour depths by about $5 \mathrm{ft}$ in each case.

\section{INTRODUCTION}

Bridge scour is the erosion of a river bed near a bridge. It can undermine foundations and is the most common cause of bridge failure in the United States (Murillo, 1987). Examples of catastrophic bridge failures in the United States involving loss of life and attributed wholly or partly to scour include the New York Thruway-Interstate 90 bridge spanning Schoharie Creek near Amsterdam, New York in 1987, the U.S. Route 51 bridge crossing the Hatchie River in Tennessee in 1989, and the Interstate 5 bridge over the Arroyo Pasajero in California in 1995 (Lagasse and others, 1995). Seventeen bridges were damaged or destroyed by scour in New York and New England in 1987 (Richardson and Davis, 2001).

Bridge scour has three components: long-term aggradation and degradation of the river bed, general scour, and local scour. Aggradation and degradation of the river bed are long-term elevation changes due to natural or human-induced causes that can affect the reach of the river on which a bridge is located. General scour is a lowering of the bed across the river at the bridge. General scour can be caused by the contraction and subsequent acceleration of flow, which results in removal of material from the bed across all or most of the channel width, or from other hydraulic conditions such as flow acceleration caused by a bend. Local scour involves removal of material from around piers, abutments, and embankments. It is caused by an acceleration of flow and vortices induced by obstructions to the flow (Richardson and Davis, 2001).

Equations and methods for estimating scour at bridges used currently (2002) are based primarily on laboratory research. Little field data have been collected to verify the applicability and accuracy of the various scour equations for the range of soil conditions, river flow conditions, and bridge designs encountered throughout the United States (Richardson and Davis, 2001). Bridge piers in Maine can be in the center of flow, where velocities typically are large during high flows (greater than, approximately, the 2-year recurrence-interval flow). To determine pier-scour depths at bridges in Maine, a cooperative study between the U.S. Geological Survey (USGS) and the Maine Department of Transportation (MDOT) began in 1997. 
This report compares the maximum pier-scour depths observed at selected bridges in Maine from 1997 through 2001 to the maximum pier-scour depths predicted using the equations in HEC- $18,4^{\text {th }}$ edition (Richardson and Davis, 2001). HEC-18 contains the Federal Highway Administration methods of computing scour in the United States. The $4^{\text {th }}$ edition contains a new adjustment factor for coarse-grained bed sediments from Mueller and Jones (1999) and other changes.

The authors would like to thank the MDOT dive team, including Jim Foster, Carl Edwards, and Mike Falla who provided valuable assistance in collecting bed-material samples at various rivers. Jim Foster and other MDOT personnel also helped in choosing the bridges used in this study, removing debris from bridge piers prior to high flows, providing lane closure assistance at some bridges, and determining the particle-size distribution of bed-material samples.

\section{DATA COLLECTION AND ANALYSIS}

\section{Collection of pier-scour data}

Data were collected at eight bridges throughout Maine (fig. 1) before, during, and after high river flows from 1997 to 2001. Initial screening of sites was accomplished by the USGS and MDOT using bridge inventories and MDOT knowledge of bridges. Potential bridge sites then were evaluated in the field by USGS personnel. Originally, it was hoped that 20 suitable bridges in Maine could be located; after field review, 12 acceptable bridges were identified. Many physical and logistic factors were considered in determining the suitability of an individual bridge for pierscour data collection. In general, the bridge sites represent a range of drainage areas, have a representative range of river bed material and pier types found in the State, and are distributed across the State. Other criteria used to select sites included the following:

1. The bridge had no rip rap or other unnatural materials around the piers.

2. The bridge provided a safe working space for personnel and scour-measuring equipment. No bridges on the Interstate Highway system were considered.

3. The river bed was composed of erodible material, not bedrock. For pier foundations set on bedrock, an ample supply of alluvial material was present so that there was no physical restraint on probable scour depths.

4. The bridge had piers with a high likelihood of scour, based on location of piers in the center of flow of a river and (or) remnant scour holes.

5. The bridge was not known to have regular jams from ice or debris.

6. Information on pier foundations and other bridge information were available from bridge plans and (or) dive reports.

Of the 12 bridges initially selected as study sites, high-flow pier scour was measured at only eight bridges. Two of the remaining four bridges were not measured because of problems such as the bridge piers being too close to the abutments. At the other two bridges, flows either were not high enough to expect scour or happened at a time when personnel could not reach the bridge for measurements.

All bridge information required for input to the HEC-18 pier-scour equations, for the eight measured bridges in this study are listed in tables 1-8. Ancillary bridge information was entered in the USGS National Bridge Scour Database (Landers and others, 1996).

\section{Low flows}

Data were collected prior to high flows at the selected bridge sites to establish baseline conditions at all piers. These data were collected annually during low-flow conditions in the summer or early fall. Depth soundings were made by use of a graduated fiberglass rod and (or) a recording fathometer mounted to a kneeboard (floating platform). Soundings were taken around all of the piers and across the upstream and downstream cross sections of the bridge. The upstream and downstream cross sections were sounded about $5 \mathrm{ft}$ upstream and downstream from the ends of the bridge piers. Special care was taken around scour holes to define the maximum scour by taking additional depth readings in and around the scoured area.

All necessary bridge dimensions were measured with measuring tapes or by surveying with an automatic level and rod. Some dimensions, especially of pier foundations, were taken from MDOT bridge plans. Any debris on the piers was photographed and quantified. All piers in this study were concrete mass piers. 


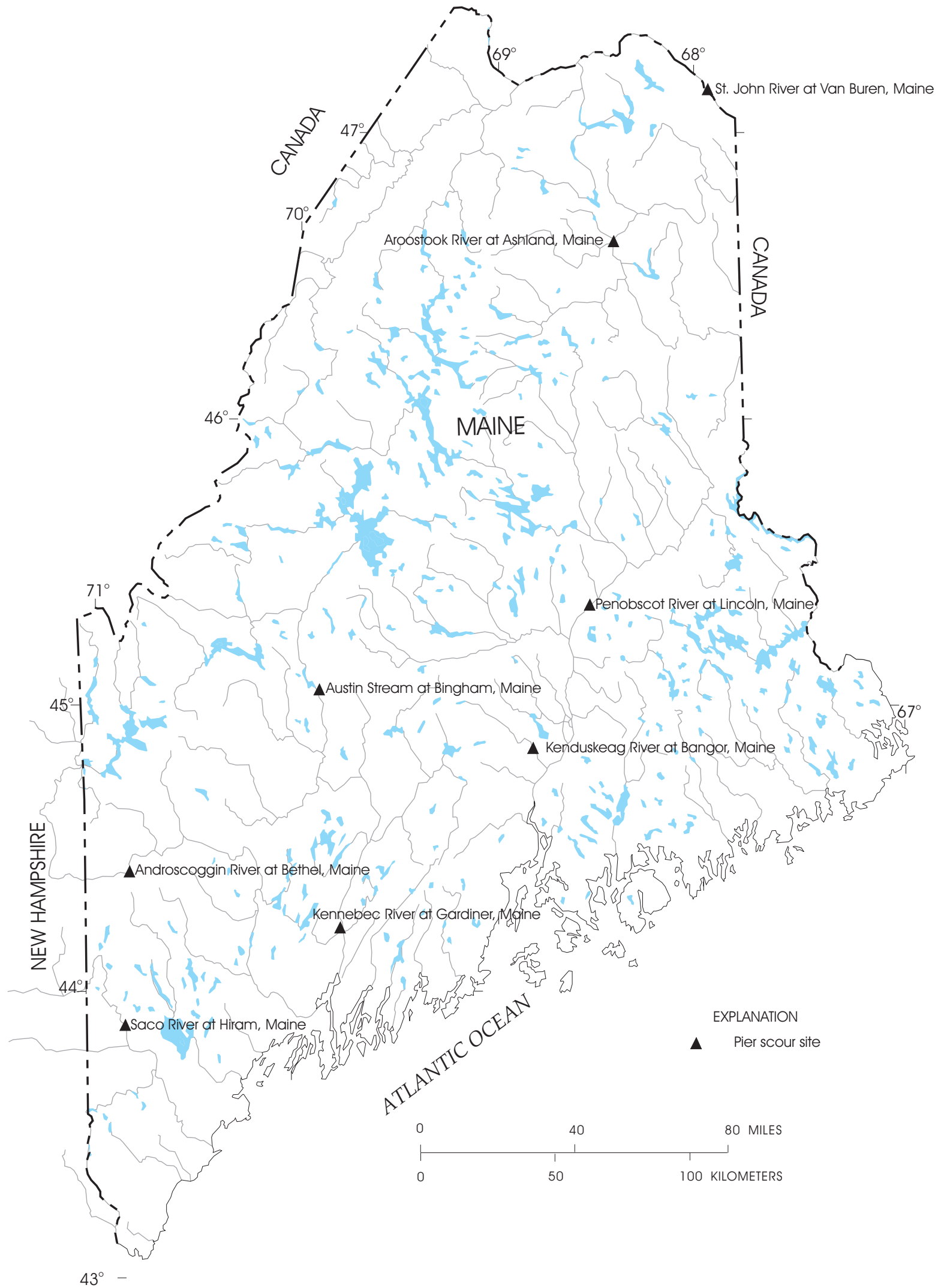

Figure 1. Location of bridges with high-flow pier-scour measurements from this study. 
Table 1. Pier-scour information for Kenduskeag River at Bangor, Maine

$\left[\mathrm{D}_{50}, \mathrm{D}_{84}, \mathrm{D}_{95}\right.$, grain size for which 50,84 , and 95 percent of material is finer; velocity, depth of flow, and pier to flow skew angle are from high-flow measurement; pier width and horizontal distance from front of pier to front of footing (f) are dimensions given the depth of flow; $\mathrm{h}_{0}$, height of footing (pile cap) above bed reference surface before scour computations; $\mathrm{mi}^{2}$, square miles; $\mathrm{ft}^{3} / \mathrm{s}$, cubic feet per second; $\mathrm{ft}$, feet; $\mathrm{ft} / \mathrm{s}$, feet per second; $\mathrm{mm}$, millimeters]

Location of site.-Lat. $44^{\circ} 51^{\prime} 41^{\prime \prime}$, long. $68^{\circ} 49^{\prime} 53^{\prime \prime}$.

Approximate drainage area. $-208 \mathrm{mi}^{2}$.

Date of high-flow measurement.-March 11, 1998.

High-flow magnitude. $-6,620 \mathrm{ft}^{3} / \mathrm{s}$.

Approximate recurrence interval.- 10 to 25 years.

Width of river at high flow. $-111 \mathrm{ft}$.

Bed material grain sizes. $-\mathrm{D}_{50}, 65 \mathrm{~mm} ; \mathrm{D}_{84}, 235 \mathrm{~mm} ; \mathrm{D}_{95}, 724 \mathrm{~mm}$.

\begin{tabular}{lc}
\hline Variable & Pier \\
\hline Velocity (ft/s) & 7.04 \\
Depth of flow (ft) & 11.8 \\
Pier to flow skew angle (degrees) & 0 \\
Pier width (ft) & 4.1 \\
Pier length (ft) & 46.5 \\
$\mathrm{f}(\mathrm{ft})$ & 3.6 \\
Pier nose shape & sharp \\
Footing width (ft) & 6.6 \\
Footing height (ft) & 6.7 \\
$\mathrm{~h}_{0}(\mathrm{ft})$ & -5.3 \\
\hline
\end{tabular}


Table 2. Pier-scour information for Kennebec River at Gardiner, Maine

$\left[\mathrm{D}_{50}, \mathrm{D}_{84}, \mathrm{D}_{95}\right.$, grain size for which 50, 84, and 95 percent of material is finer; piers numbered from left river bank, looking downstream; velocity, depth of flow, and pier to flow skew angle are from high-flow measurement; pier width and horizontal distance from front of pier to front of footing (f) are dimensions given the depth of flow; $\mathrm{h}_{0}$, height of footing (pile cap) above bed reference surface before scour computations; $\mathrm{mi}^{2}$, square miles; $\mathrm{ft}^{3} / \mathrm{s}$, cubic feet per second; $\mathrm{ft}$, feet; $\mathrm{ft} / \mathrm{s}$, feet per second; $\mathrm{mm}$, millimeters]

Location of site.-Lat. $44^{\circ} 13$ ' $59^{\prime \prime}$, long. $69^{\circ} 46^{\prime} 13$ '.

Approximate drainage area. $-5,540 \mathrm{mi}^{2}$.

Date of high-flow measurement.-April 2, 1998.

High-flow magnitude. $-80,000 \mathrm{ft}^{3} / \mathrm{s}$.

Approximate recurrence interval.- 2 to 5 years.

Width of river at high flow. $-890 \mathrm{ft}$.

Bed material grain sizes. $-\mathrm{D}_{50}, 37 \mathrm{~mm} ; \mathrm{D}_{84}, 100 \mathrm{~mm}$; $\mathrm{D}_{95}, 165 \mathrm{~mm}$.

\begin{tabular}{lcccc}
\hline Variable & Pier 1 & Pier 2 & Pier 3 & Pier 4 \\
\hline Velocity (ft/s) & 2.82 & 4.42 & 5.78 & 3.54 \\
Depth of flow (ft) & 13.0 & 23.4 & 30.5 & 30.2 \\
Pier to flow skew angle (degrees) & 10 & 2 & 10 & 3 \\
Pier width (ft) & 8.3 & 8.9 & 9.4 & 9.4 \\
Pier length (ft) & 75.1 & 76.9 & 78.8 & 78.8 \\
$\mathrm{f}(\mathrm{ft})$ & 1.0 & 9.2 & 10.2 & 8.0 \\
Pier nose shape & round & round & round & round \\
Footing width (ft) & 11.0 & 15.7 & 16.1 & 16.1 \\
Footing height (ft) & 16.0 & 17.5 & 20.0 & 20.0 \\
$\mathrm{~h}_{0}(\mathrm{ft})$ & -15.1 & -10.7 & -9.7 & -9.8 \\
\hline
\end{tabular}


Table 3. Pier-scour information for Androscoggin River at Bethel, Maine

$\left[\mathrm{D}_{50}, \mathrm{D}_{84}, \mathrm{D}_{95}\right.$, grain size for which 50,84 , and 95 percent of material is finer; piers numbered from left river bank, looking downstream; velocity, depth of flow, and pier to flow skew angle are from high-flow measurement; pier width and horizontal distance from front of pier to front of footing (f) are dimensions given the depth of flow; $\mathrm{h}_{0}$, height of footing (pile cap) above bed reference surface before scour computations; $\mathrm{mi}^{2}$, square miles; $\mathrm{ft}^{3} / \mathrm{s}$, cubic feet per second; ft, feet; ft/s, feet per second; $\mathrm{mm}$, millimeters]

Location of site.-Lat. $44^{\circ} 24^{\prime} 59^{\prime \prime}$, long. $70^{\circ} 47^{\prime} 50^{\prime \prime}$.

Approximate drainage area. $-1,650 \mathrm{mi}^{2}$.

Date of high-flow measurement.—April 1, 1998.

High-flow magnitude. $-29,300 \mathrm{ft}^{3} / \mathrm{s}$.

Approximate recurrence interval. -25 years.

Width of river at high flow. $-340 \mathrm{ft}$.

Bed material grain sizes. $-D_{50}, 23 \mathrm{~mm} ; D_{84}, 85 \mathrm{~mm} ; D_{95}, 181 \mathrm{~mm}$.

\begin{tabular}{lcc}
\hline Variable & Pier 1 & Pier 2 \\
\hline Velocity (ft/s) & 6.82 & 4.55 \\
Depth of flow (ft) & 17.5 & 17.4 \\
Pier to flow skew angle (degrees) & 8 & 8 \\
Pier width (ft) & 7.0 & 7.0 \\
Pier length (ft) & 32.0 & 32.0 \\
$\mathrm{f}(\mathrm{ft})$ & 4.0 & 4.0 \\
Pier nose shape & round & round \\
Footing width (ft) & 9.9 & 9.8 \\
Footing height (ft) & 10.5 & 10.5 \\
$\mathrm{~h}_{0}(\mathrm{ft})$ & -8.4 & -8.6 \\
\hline
\end{tabular}


Table 4. Pier-scour information for Penobscot River at Lincoln, Maine

$\left[D_{50}, D_{84}, D_{95}\right.$, grain size for which 50, 84, and 95 percent of material is finer; piers numbered from left river bank, looking downstream; velocity, depth of flow, and pier to flow skew angle are from high-flow measurement; pier width and horizontal distance from front of pier to front of footing (f) are dimensions given the depth of flow; $\mathrm{h}_{0}$, height of footing (pile cap) above bed reference surface before scour computations; $\mathrm{mi}^{2}$, square miles; $\mathrm{ft}^{3} / \mathrm{s}$, cubic feet per second; $\mathrm{ft}$, feet; $\mathrm{ft} / \mathrm{s}$, feet per second; $\mathrm{mm}$, millimeters]

Location of site.-Lat. $45^{\circ} 21^{\prime} 44^{\prime \prime}$, long. $68^{\circ} 32^{\prime}$ '53'.

Approximate drainage area. $-5,110 \mathrm{mi}^{2}$.

Date of high-flow measurement.-April 3, 1998.

High-flow magnitude. $-43,000 \mathrm{ft}^{3} / \mathrm{s}$.

Approximate recurrence interval. -2 years.

Width of river at high flow. $-1,058 \mathrm{ft}$.

Bed material grain sizes. $-\mathrm{D}_{50}, 3.8 \mathrm{~mm} ; \mathrm{D}_{84}, 49 \mathrm{~mm} ; \mathrm{D}_{95}, 90 \mathrm{~mm}$.

\begin{tabular}{lcccccc}
\hline Variable & Pier 1 & Pier 2 & Pier 3 & Pier 4 & Pier 5 & Pier 6 \\
\hline Velocity (ft/s) & 3.06 & 3.40 & 3.53 & 2.67 & 3.67 & 4.10 \\
Depth of flow (ft) & 10.7 & 17.7 & 10.7 & 11.9 & 14.4 & 11.0 \\
Pier to flow skew angle (degrees) & 1 & 7 & 5 & 1 & 5 & 5 \\
Pier width (ft) & 7.5 & 7.5 & 7.5 & 7.5 & 7.5 & 7.5 \\
Pier length (ft) & 37 & 37 & 37 & 37 & 37 & 37 \\
f (ft) & 3.1 & 4.4 & 4.4 & 4.4 & 4.4 & 4.4 \\
Pier nose shape & round & round & round & round & round & round \\
Footing width (ft) & 13.8 & 15.4 & 14.2 & 14.5 & 14.3 & 13.8 \\
Footing height (ft) & 11.0 & 12.0 & 10.0 & 10.0 & 12.0 & 11.0 \\
$\mathrm{~h}_{0}(\mathrm{ft})$ & -11.0 & -5.3 & -8.4 & -7.0 & -10.0 & -10.6 \\
\hline
\end{tabular}


Table 5. Pier-scour information for Aroostook River at Ashland, Maine

$\left[\mathrm{D}_{50}, \mathrm{D}_{84}, \mathrm{D}_{95}\right.$, grain size for which 50,84 , and 95 percent of material is finer; piers numbered from left river bank, looking downstream; velocity, depth of flow, and pier to flow skew angle are from high-flow measurement; pier width and horizontal distance from front of pier to front of footing (f) are dimensions given the depth of flow; $\mathrm{h}_{0}$, height of footing (pile cap) above bed reference surface before scour computations; $\mathrm{mi}^{2}$, square miles; $\mathrm{ft}^{3} / \mathrm{s}$, cubic feet per second; ft, feet; ft/s, feet per second; $\mathrm{mm}$, millimeters]

Location of site.-Lat. $46^{\circ} 37^{\prime} 54^{\prime \prime}$, long. $68^{\circ} 25^{\prime} 09^{\prime \prime}$.

Approximate drainage area. $-1,340 \mathrm{mi}^{2}$.

Date of high-flow measurement.-April 25, 2000.

High-flow magnitude. $-22,700 \mathrm{ft}^{3} / \mathrm{s}$.

Approximate recurrence interval. -2 to 5 years.

Width of river at high flow. $-332 \mathrm{ft}$.

Bed material grain sizes. $-D_{50}, 43 \mathrm{~mm} ; \mathrm{D}_{84}, 83 \mathrm{~mm} ; \mathrm{D}_{95}, 205 \mathrm{~mm}$.

\begin{tabular}{lcc}
\hline Variable & Pier 1 & Pier 2 \\
\hline Velocity (ft/s) & 6.20 & 6.88 \\
Depth of flow (ft) & 13.7 & 14.0 \\
Pier to flow skew angle (degrees) & 2 & 11 \\
Pier width (ft) & 4.0 & 4.0 \\
Pier length (ft) & 47 & 47 \\
$\mathrm{f}(\mathrm{ft})$ & 6.0 & 6.0 \\
Pier nose shape & sharp & sharp \\
Footing width (ft) & 8.3 & 8.7 \\
Footing height (ft) & 11.7 & 11.7 \\
$\mathrm{~h}_{0}(\mathrm{ft})$ & -7.2 & -6.9 \\
\hline
\end{tabular}


Table 6. Pier-scour information for St. John River at Van Buren, Maine

$\left[\mathrm{D}_{50}, \mathrm{D}_{84}, \mathrm{D}_{95}\right.$, grain size for which 50, 84, and 95 percent of material is finer; piers numbered from left river bank, looking downstream; velocity, depth of flow, and pier to flow skew angle are from high-flow measurement; pier width and horizontal distance from front of pier to front of footing (f) are dimensions given the depth of flow; $\mathrm{h}_{0}$, height of footing (pile cap) above bed reference surface before scour computations; $\mathrm{mi}^{2}$, square miles; $\mathrm{ft}^{3} / \mathrm{s}$, cubic feet per second; $\mathrm{ft}$, feet; $\mathrm{ft} / \mathrm{s}$, feet per second; $\mathrm{mm}$, millimeters]

Location of site.-Lat. $47^{\circ} 09^{\prime} 34^{\prime \prime}$, long. $67^{\circ} 55^{\prime} 52^{\prime}$ '.

Approximate drainage area. $-8,170 \mathrm{mi}^{2}$.

Date of high-flow measurement.-April 27, 2001.

High-flow magnitude. $-111,000 \mathrm{ft}^{3} / \mathrm{s}$.

Approximate recurrence interval. -2 years.

Width of river at high flow.- $682 \mathrm{ft}$.

Bed material grain sizes. $-\mathrm{D}_{50}, 104 \mathrm{~mm} ; \mathrm{D}_{84}, 170 \mathrm{~mm} ; \mathrm{D}_{95}, 256 \mathrm{~mm}$.

\begin{tabular}{lcccc}
\hline Variable & Pier 1 & Pier 2 & Pier 3 & Pier 4 \\
\hline Velocity (ft/s) & 6.35 & 7.28 & 6.89 & 4.60 \\
Depth of flow (ft) & 22.3 & 30.8 & 22.6 & 18.4 \\
Pier to flow skew angle (degrees) & 0 & 0 & 0 & 0 \\
Pier width (ft) & 4.0 & 6.0 & 6.0 & 4.0 \\
Pier length (ft) & 30.0 & 31.0 & 31.0 & 30.0 \\
$\mathrm{f}(\mathrm{ft})$ & 0.5 & 0.5 & 0.5 & 0.5 \\
Pier nose shape & sharp & sharp & sharp & sharp \\
Footing width (ft) & 13.0 & 11.0 & 11.2 & 10.0 \\
Footing height (ft) & 11.5 & 11.5 & 11.5 & 11.5 \\
$\mathrm{~h}_{0}(\mathrm{ft})$ & -6.8 & -9.6 & -9.3 & -13.8 \\
\hline
\end{tabular}


Table 7. Pier-scour information for Austin Stream at Bingham, Maine

$\left[\mathrm{D}_{50}, \mathrm{D}_{84}, \mathrm{D}_{95}\right.$, grain size for which 50,84 , and 95 percent of material is finer; piers numbered from left river bank, looking downstream; velocity, depth of flow, and pier to flow skew angle are from high-flow measurement; pier width and horizontal distance from front of pier to front of footing (f) are dimensions given the depth of flow; $\mathrm{h}_{0}$, height of footing (pile cap) above bed reference surface before scour computations; $\mathrm{mi}^{2}$, square miles; $\mathrm{ft}^{3} / \mathrm{s}$, cubic feet per second; ft, feet; ft/s, feet per second; $\mathrm{mm}$, millimeters]

Location of site.-Lat. $45^{\circ} 03^{\prime} 44^{\prime \prime}$, long. $69^{\circ} 52^{\prime}$ '59'.

Approximate drainage area. $-90.0 \mathrm{mi}^{2}$.

Date of high-flow measurement.-March 29, 2000.

High-flow magnitude. $-2,750 \mathrm{ft}^{3} / \mathrm{s}$.

Approximate recurrence interval. -2 to 5 years.

Width of river at high flow. $-145 \mathrm{ft}$.

Bed material grain sizes. $-D_{50}, 61 \mathrm{~mm} ; \mathrm{D}_{84}, 120 \mathrm{~mm} ; \mathrm{D}_{95}, 162 \mathrm{~mm}$.

\begin{tabular}{lcc}
\hline Variable & Pier 1 & Pier 2 \\
\hline Velocity (ft/s) & 7.89 & 7.06 \\
Depth of flow (ft) & 4.2 & 2.7 \\
Pier to flow skew angle (degrees) & 20 & 16 \\
Pier width (ft) & 4.6 & 4.6 \\
Pier length (ft) & 65 & 65 \\
$\mathrm{f}(\mathrm{ft})$ & 3.0 & 3.0 \\
Pier nose shape & sharp & sharp \\
Footing width (ft) & 12.0 & 12.0 \\
Footing height (ft) & 4.5 & 4.5 \\
$\mathrm{~h}_{0}(\mathrm{ft})$ & -4.3 & -5.8 \\
\hline
\end{tabular}


Table 8. Pier-scour information for Saco River at Hiram, Maine

$\left[D_{50}, D_{84}, D_{95}\right.$, grain size for which 50, 84, and 95 percent of material is finer; velocity, depth of flow, and pier to flow skew angle are from high-flow measurement; pier width and horizontal distance from front of pier to front of footing (f) are dimensions given the depth of flow; $\mathrm{h}_{0}$, height of footing (pile cap) above bed reference surface before scour computations; $\mathrm{mi}^{2}$, square miles; $\mathrm{ft}^{3} / \mathrm{s}$, cubic feet per second; $\mathrm{ft}$, feet; ft/s, feet per second; mm, millimeters]

Location of site.-Lat. $43^{\circ} 52^{\prime} 41^{\prime \prime}$, long. $70^{\circ} 48^{\prime} 16^{\prime \prime}$.

Approximate drainage area. $-790 \mathrm{mi}^{2}$.

Dates of high-flow measurements.-April 22, 1997; June 17, 1998.

High-flow magnitude. $-11,000 \mathrm{ft}^{3} / \mathrm{s}, 1997 ; 16,000 \mathrm{ft}^{3} / \mathrm{s}, 1998$.

Approximate recurrence interval.-2 to 5 years, 1997; 10-25 years, 1998.

Width of river at high flow. $-230 \mathrm{ft}, 1997 ; 232 \mathrm{ft}, 1998$.

Bed material grain sizes. $-\mathrm{D}_{50}, 1.0 \mathrm{~mm} ; \mathrm{D}_{84}, 2.8 \mathrm{~mm} ; \mathrm{D}_{95}, 4.3 \mathrm{~mm}$.

\begin{tabular}{lcc}
\hline Variable & Pier, 1997 & Pier, 1998 \\
\hline Velocity (ft/s) & 4.04 & 5.18 \\
Depth of flow (ft) & 18.4 & 21.8 \\
Pier to flow skew angle (degrees) & 0 & 0 \\
Pier width (ft) & 5.7 & 5.5 \\
Pier length (ft) & 52.4 & 51.8 \\
$\mathrm{f}(\mathrm{ft})$ & 2.8 & 2.8 \\
Pier nose shape & sharp & sharp \\
Footing width (ft) & 10.5 & 10.5 \\
Footing height (ft) & 23.0 & 23.0 \\
$\mathrm{~h}_{0}(\mathrm{ft})$ & -25.3 & -25.3 \\
\hline
\end{tabular}


River bed material upstream from the bridges with high-flow scour measurements was collected and classified by grain size after a high-flow measurement was made at a bridge. The method of collection and classification varied by the size of the bed material. For rivers with sand-bed channels (median grain size of less than $2 \mathrm{~mm}$, only the Saco River at Hiram, Maine (fig. 1) met this criteria), bed material was collected using a US BMH-60 bed-material sampler. The location and number of sediment samples in the approach cross section (one bridge length upstream of the bridge) followed the methods described in Hayes (1993), which were modifications of methods described in Ashmore and others (1988) and International Organization for Standardization (1977). Five replicate samples were collected and combined at three locations (approximately 25, 50, and 75 percent of the crosssection width) in the approach cross section, and at equivalent locations in cross sections $50 \mathrm{ft}$ upstream and $50 \mathrm{ft}$ downstream of the approach cross section. The grain-size distribution was computed by the MDOT Soils Laboratory by sorting and weighing the sample using American Association of State Highway and Transportation Officials (AASHTO) T27 sieve analyses (AASHTO, 2001).

Grid sampling was used to collect and classify bed sediment material at rivers with coarse-grained bed sediments (median grain size greater than $2 \mathrm{~mm}$ ) where the coarse-grained sediments were all or mostly continuous across the approach section. The location and number of sediment samples in the approach cross section to each bridge followed the methodology in Hayes (1993), which were modifications of methods described in Yuzyk (1986) and International Organization for Standardization (1989). Data collection involved sampling approximately 100 sediment particles at evenly spaced intervals across the approach cross section. The same data-collection method was used at cross sections $50 \mathrm{ft}$ above and $50 \mathrm{ft}$ below the approach cross section. The particles were classified using a gravel template with standard-size square openings. When a river could not be waded for the grid sampling (St. John River at Van Buren, Maine; Kennebec River at Gardiner, Maine), MDOT divers collected the samples at the approach section only, because of limitations on dive time, and measured the b-axis of the samples (where the a-axis of a particle is the longest dimension and the c-axis is the shortest dimension) rather than using the gravel template.
At two of the bridge-scour sites, the approach cross sections consisted of discontinuous coarsegrained sediments (Androscoggin River at Bethel, Maine; Penobscot River at Lincoln, Maine). Substantial amounts of sand were present between the coarse grains. At these sites, a modification of the bulk sampling procedure in Yuzyk (1986) was used. MDOT divers removed the top 2 in. of bed material from inside a fabricated round 20 in. diameter steel "cookie cutter". Three replicate samples were collected at four locations in the approach cross section (at approximately $20,40,60$, and 80 percent of the cross-section width) and combined. The total weight of the samples (about $600 \mathrm{lb}$ ) exceeded the minimum sample size required for the bulk sampling method in Yuzyk (1986). The bed material was classified using a combination of the gravel template, a weighing scale, and MDOT T27 sieve analyses.

\section{High flows}

Pier scour generally occurs during high flows, when the energy of a river is high. This study attempted to measure pier scour at the time of the largest flow that occurred at the sites from 1997 through 2001. Precipitation data collected from rain gages and real-time river flow information near the sites were monitored to direct measurement efforts at or near peak flows. Because the magnitude of future flows are unknown, the estimated 2-year recurrence interval flow (the peak flow that is expected to occur, on average, once every 2 years) at each site was used as a guideline for a minimum flow needed to make high-flow scour measurements. All measurements were made in the spring during high flows associated with snowmelt runoff. Ten high-flow scour measurements were made at eight sites in Maine. One of these high-flow measurements was removed from the analysis, as explained later. Six of the high-flow scour measurements were made at bridges with multiple piers.

Various data were collected during high-flow measurements. A standard USGS river flow measurement was made, using Columbus sounding weights and a Price AA velocity meter (Rantz and others, 1982), on the upstream side of the bridge. The weights and velocity meter were suspended from a truck-mounted crane with an extendable boom. The boom could be extended 6 to $8 \mathrm{ft}$ upstream from the bridge deck. The river-flow measurement included the necessary velocity measurements near the piers and the depth measurements (about 25) across the upstream cross 
section. Additional depth measurements were then taken near piers, with $100 \mathrm{lb}$ to $300 \mathrm{lb}$ of weight (fig. 2 ), usually in a 2-ft grid, until the person making the measurements was confident that the maximum scour near the nose of the pier had been measured. Riverheight measurements, from a local datum, were taken before, during (if necessary), and after the river flow and depth measurements. Photographs were taken of the flow conditions at the bridge, around the piers, and in the upstream and downstream channel (figs. 3-4).

When piers are skewed to the direction of the flow, the maximum scour depth can be located along the sides or downstream from the pier. In this study, two sites (Aroostook River at Ashland, Maine and Austin Stream at Bingham, Maine) had a pier to flow skew angle greater than 10 degrees. The maximum observed scour at these piers either was along the side of the pier or near the nose. The remaining six bridges had skew angles of 0 to 10 degrees. The maximum pier scour at all of these six bridges was near the nose of the piers, based on measurements before, during, and after high-flow measurements.

Approximate recurrence intervals were calculated for each of the measured high flows in this study (tables 1-8) using the drainage-area adjustment methods in Hodgkins (1999). The recurrence interval is the average period of time between peak flows that are equal to or greater than a specified peak flow. The drainage-area adjustments are not applicable to the regulated streams in this study (Androscoggin, Kennebec, and Penobscot Rivers), but they probably are the best method available for computing recurrence intervals at these sites. Also, the drainage areas for several sites were interpolated from points of known drainage areas on the rivers. The approximate recurrence intervals of the measured flows in this study ranged from 2 to 25 years.

Based on measurements made during this study, and on bridge inspections by MDOT divers for a few years prior to this study, scour holes at Maine bridge piers do not completely fill in after a high flow. The pier-scour holes did not change position during this study at any of the bridges in the study, except where debris lodged on a pier after a measurement. The scour depths on the sides of piers were not measured during high flows. For sites where the maximum scour was not near the nose of the pier; measurements before, during, and after high flows were analyzed. The high-flow maximum scour at these sites was confidently calcu- lated at the Aroostook River and for one of two highflow measurements at Austin Stream. It was not confidently calculated for the second Austin Stream measurement. This measurement at Austin Stream was not used in the comparison of observed and predicted scour. After this measurement was removed from the analysis, 23 high-flow pier-scour measurements from 9 high flows at 8 bridges were used in the comparison.

\section{Computation of pier-scour depths}

Twenty-three high-flow pier-scour measurements were made in Maine from 1997 to 2001. For these pier-scour measurements, the maximum predicted pier-scour depths were computed using Federal Highway Administration equations (Richardson and Davis, 2001). The following two sections describe the methods of computing the observed and predicted pier-scour depths.

\section{Observed}

The maximum observed pier scour from the high-flow measurements was computed using the concurrent ambient bed level method, as described by Landers and Mueller (1993). In this method, the maximum scour is the maximum vertical distance from the locally scoured bed to a reference surface line. The reference surface line connects one side of the bed, outside of the local scour hole, to the other side. All depths measured during high flows were used to plot the upstream cross section at each site. The depth of the bed outside of the scour hole was refined, in some cases, by looking at the upstream and downstream depths from low-flow soundings. The concurrent ambient bed level method removes any effect of longterm aggradation or degradation scour, and general scour (including contraction scour) on the observed pier-scour depths.

Scour holes were present at many sites prior to the high-flow measurements of this study (fig. 5, for example). It is possible that the observed maximum pier-scour depths in this study were not caused by the measured high flows. The scour holes measured during high flows in this study may be remnants of scour holes from previous high flows, or from previous flows in combination with woody debris or ice on the piers. For all non-zero observed pier-scour depths from the highflow pier-scour measurements in this study, an analysis was made to determine if the event had the necessary 


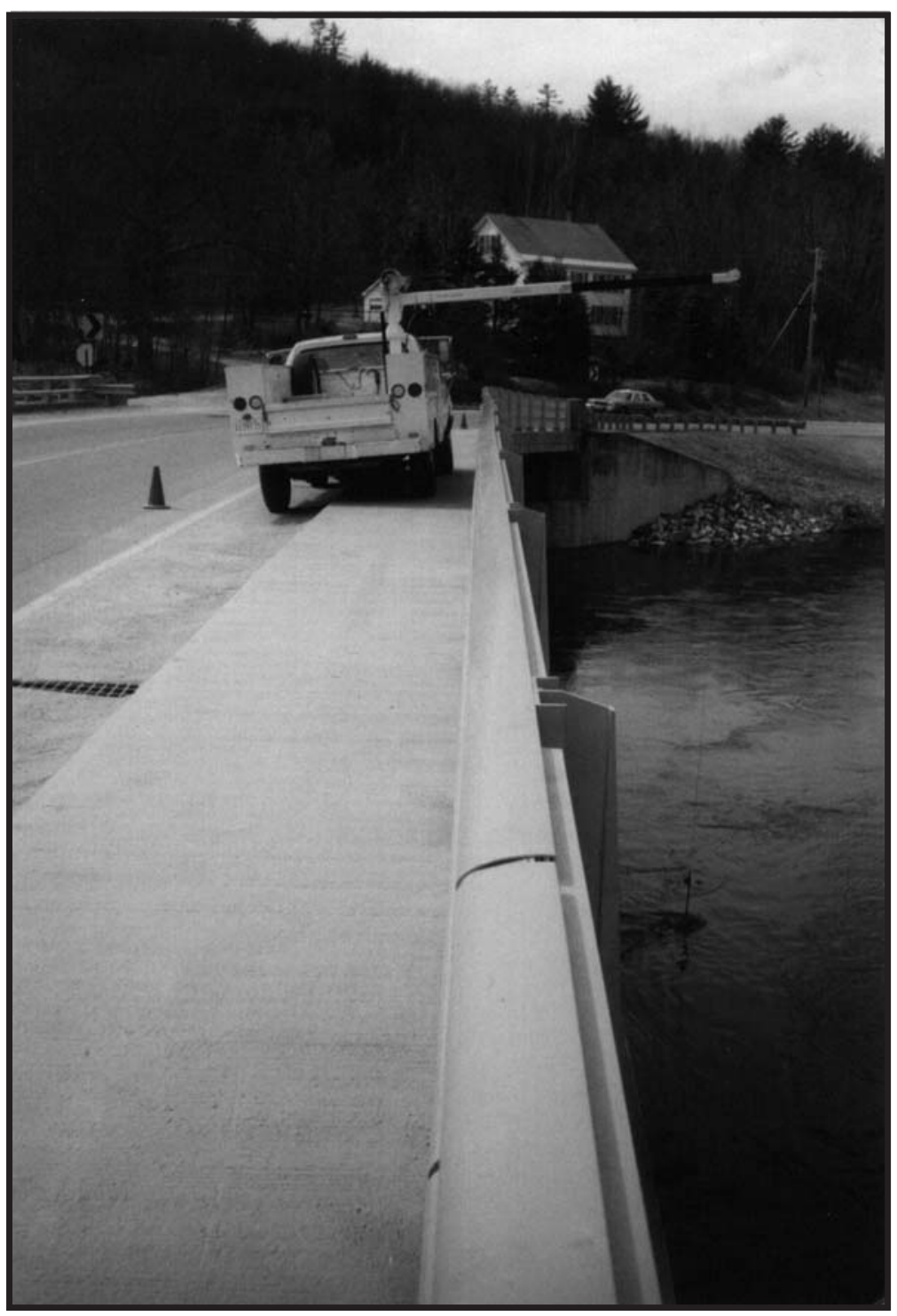

Figure 2. Equipment used for measuring water depth at Saco River at Hiram, Maine, April 22, 1997. 


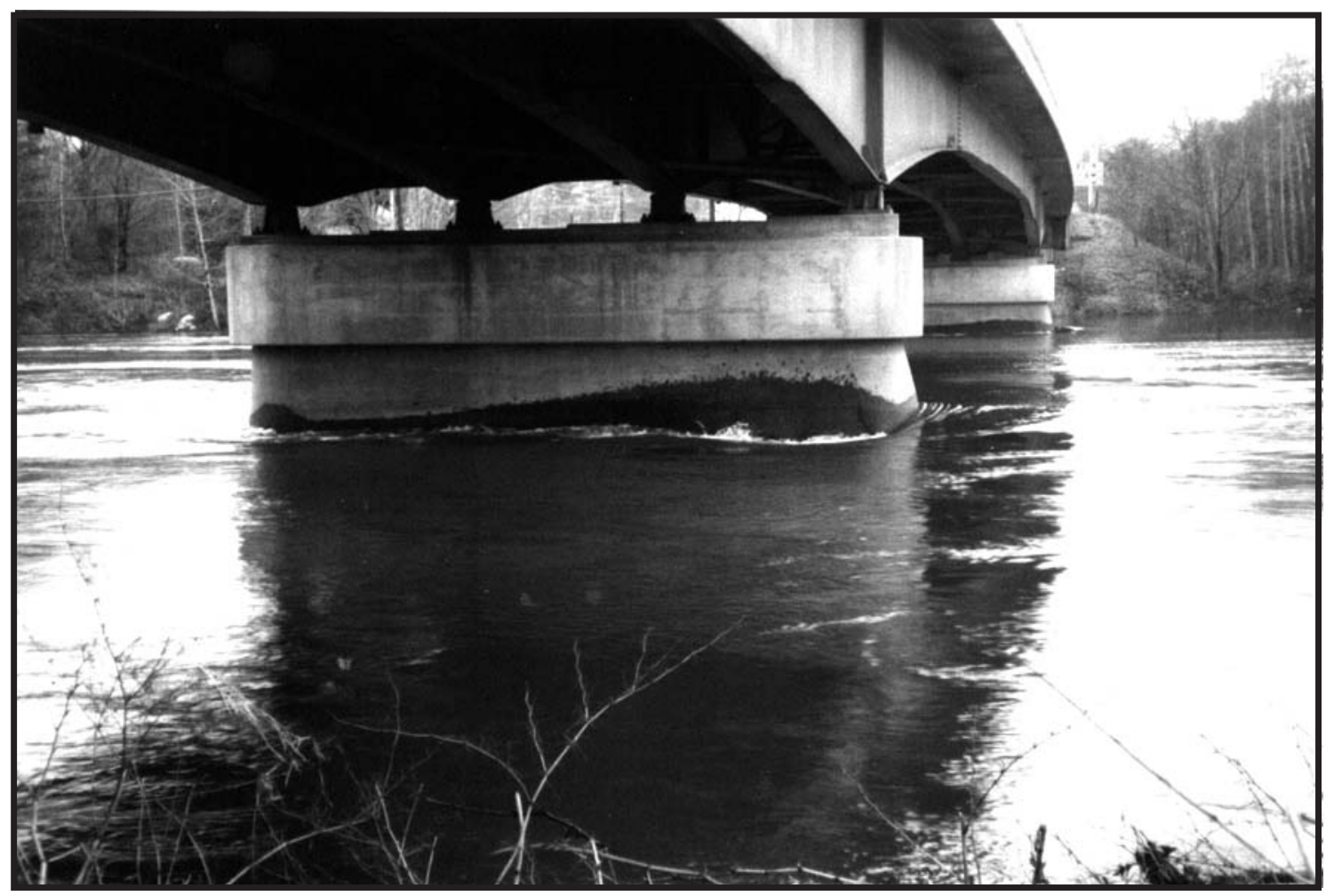

Figure 3. River flow near bridge piers on Androscoggin River at Bethel, Maine, April 1, 1998.

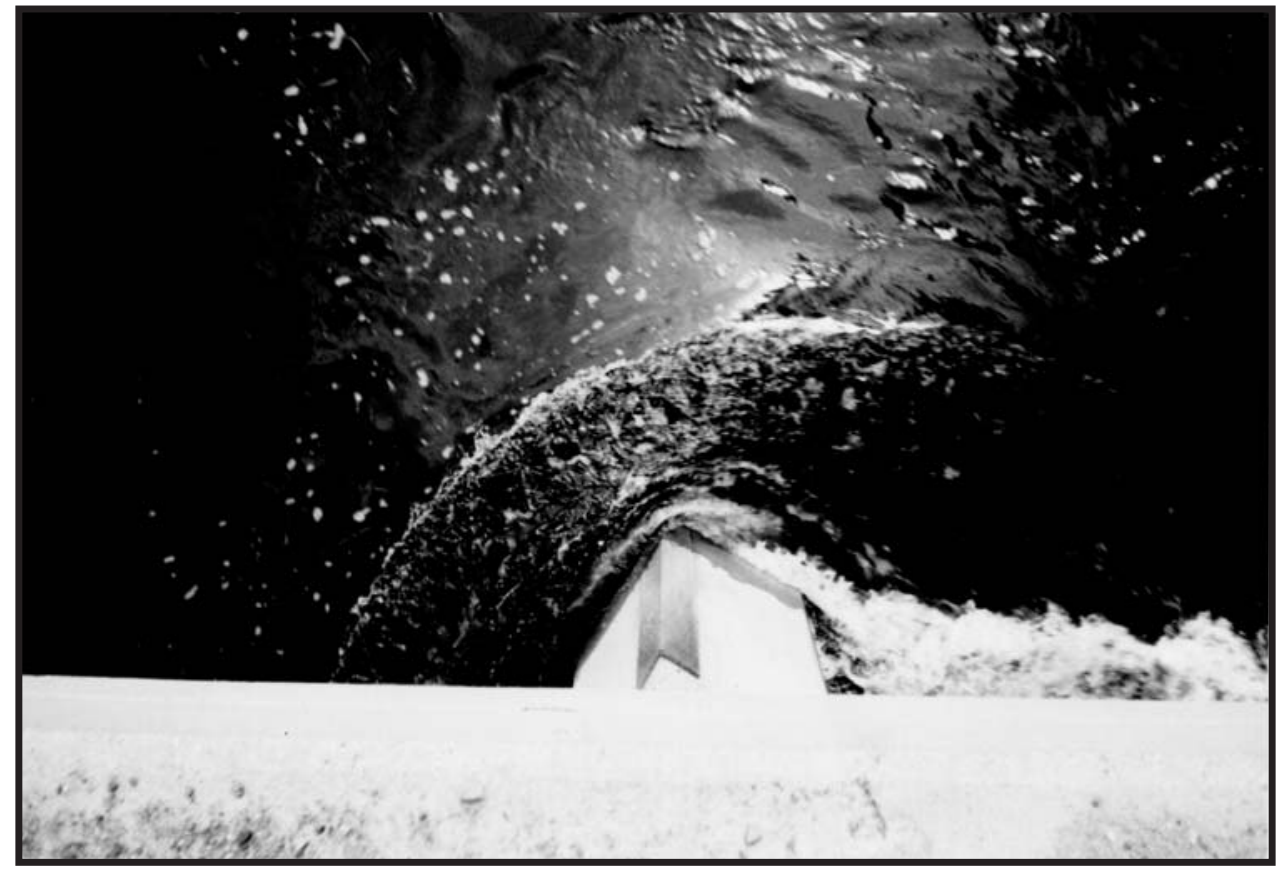

Figure 4. Flow turbulence at the upstream nose of the right (looking downstream) bridge pier at Aroostook River at Ashland, Maine, April 25, 2000. 


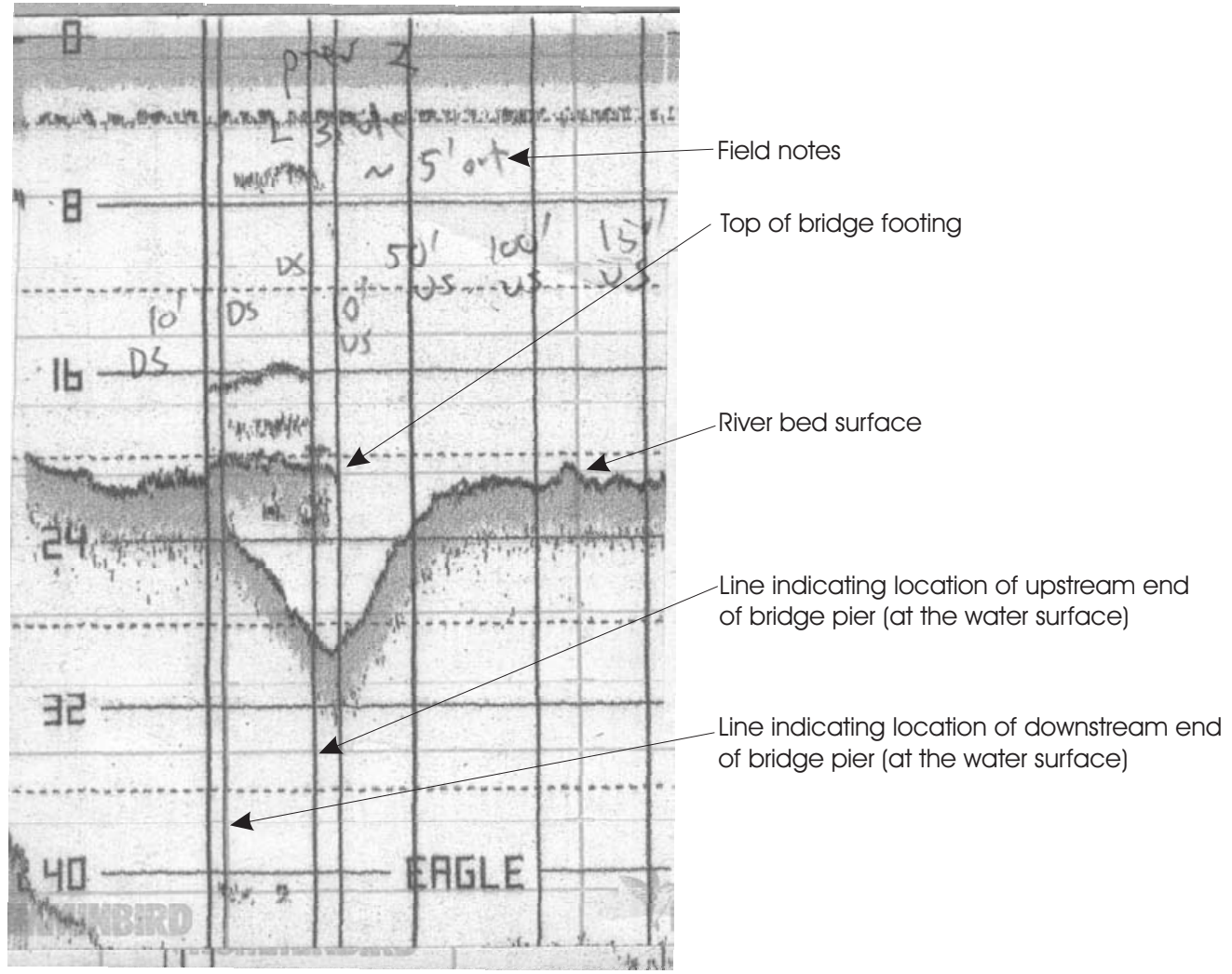

Figure 5. Fathometer record of bridge pier-scour hole at the 2nd pier from left (looking downstream) bank at St. John River at Van Buren, Maine, September 3, 1998. [Numbers are depth in feet below water surface. Vertical lines are field marks on the fathometer tape used to indicate location]. 
theoretical velocities to cause scour. The theoretical approach velocity required to initiate scour at a pier for the $\mathrm{D}_{10}$ grain size (10 percent of the riverbed material is finer than $\mathrm{D}_{10}$ grain size) was calculated (Richardson and Davis, 2001). Even though this velocity would theoretically not move the $\mathrm{D}_{50}$ (median) grain size, scour would be possible as the fines were carried away and the remaining materials dropped in elevation. All pier-approach velocities measured in this study were greater than the approach velocity required to move the $\mathrm{D}_{10}$-sized particles at piers with measured non-zero pier scour. Some of the measured high flows in this study still may not have been capable of causing the scour that is associated with them.

\section{Predicted}

Data collected at bridge sites during high and low flows (tables 1-8) were used to compute predicted maximum pier-scour depths using the equations in HEC-18, $4^{\text {th }}$ edition (Richardson and Davis, 2001). The HEC-18 equations use various variables to compute pier scour: the river flow depth and velocity upstream of the pier; the pier and pier foundation widths, lengths, and heights; the pier nose shape; the flow to pier skew angle; the bed condition (plane bed or dunes); the bed material grain-size distribution; the horizontal distance from the upstream edge of the pier to the upstream edge of the pier footing; and the height of the pier footing above or below the bed reference surface. The bed condition for all rivers in this study was assumed to be plane bed. The ranges of selected variables from the 23 piers with high-flow scour measurements are listed in table 9.

Various piers in the study tapered outward from top to bottom. For these cases, the pier width was calculated as the average width between the high-flow measurement river height and the bottom of the pier stem. Many bridges in Maine have multi-part pier footings with a footing (pile cap) topped by a smaller spread footing. Often, piles are located under the footings. If the pier footing was exposed (top of pier footing higher than the reference surface described in the previous section) or if the pier-scour depth computed from the basic HEC-18 equation (equation 6.1 in HEC18) exposed the pier footing, the "superposition of scour components" method of analysis in HEC-18 was used. This superposition analysis involves separate computation, and subsequent addition, of the pier scour caused by the pier, the footing, and the piles. Footings were exposed at many of the study sites. Piles were not exposed at any of the sites. HEC-18 computations do not have a mechanism for handling complex footings. For any calculations involving pier scour caused by the footing, the average width from the top of the spread footing to the average scour depth (maximum scour depth divided by 2 , as recommended in HEC-18) was used for the footing width. The horizontal distance from the front of the pier to the front of the spread footing was used in the computations, if only the spread footing was exposed. The distance from the front of the pier to the front of the footing (pile cap) was used, if the footing also was exposed.

\section{OBSERVED AND PREDICTED PIER- SCOUR DEPTHS}

The ranges of selected pier-scour variables from the 23 piers where data were collected during high flows are listed in table 9 . The maximum observed pier-scour depths from this study are listed in table 10 . These depths are considered accurate to $0.5 \mathrm{ft}$. Pier scour greater than $0.5 \mathrm{ft}$ was documented at all eight bridges in this study. Fifteen out of 23 piers that were measured had pier scour ranging from 0.5 to $12.0 \mathrm{ft}$. No pier scour was observed at the remaining eight piers. Observed non-zero pier scour averaged $4.2 \mathrm{ft}$.

The HEC-18 pier-scour equations are envelope equations. Envelope equations make conservative predictions. This conservative prediction is a desirable quality when the consequences of structural failure are catastrophic. In the case of pier scour, the actual pierscour depths preferably would never be greater than the predicted pier-scour depths, and the difference between them would be minimal. The HEC-18 equations were chosen by Richardson and Davis (2001), and by previous editions of HEC-18, using this criteria. This choice was based on a study by Jones (1984). Mueller (1996) concluded that the HEC-18 equations were good for design purposes because they rarely underpredicted measured scour depths, however, they frequently overpredicted the observed scour. Mueller compared predicted and observed pier scour for 22 prediction equations. This comparison was based on 224 measurements of scour at 90 bridge piers in the United States. None of these 22 equations both accurately predicted pier scour and was sufficiently conservative for use in design (Mueller, 1996). 
Table 9. Range of selected pier-scour data from 23 piers in Maine during high flows [ft, feet; ft/s, feet per second; mm, millimeters ]

\begin{tabular}{lcc}
\hline Variable & Minimum & Maximum \\
\hline Median bed-material grain size (mm) & 1.0 & 104 \\
River flow velocity at piers (ft/s) & 2.67 & 7.89 \\
Depth of flow (ft) & 2.7 & 30.8 \\
Pier to flow skew angle (degrees) & 0 & 20 \\
Pier width (ft) & 4.0 & 9.4 \\
Footing width (ft) & 6.6 & 16.1 \\
\hline
\end{tabular}


Table 10. Predicted and observed maximum pier-scour depths from 23 piers in Maine during high flows

[Piers numbered from left bank, looking downstream; ft, feet]

\begin{tabular}{|c|c|c|c|}
\hline Pier-scour site & Predicted (ft) & Observed (ft) & $\begin{array}{l}\text { Predicted minus } \\
\text { observed (ft) }\end{array}$ \\
\hline Kenduskeag River at Bangor & 8.3 & 1.1 & 7.2 \\
\hline Kennebec River at Gardiner 1 & 19.5 & 1.7 & 17.8 \\
\hline Kennebec River at Gardiner 2 & 18.6 & 6.8 & 11.8 \\
\hline Kennebec River at Gardiner 3 & 12.6 & 3.4 & 9.2 \\
\hline Kennebec River at Gardiner 4 & 18.2 & 0 & 18.2 \\
\hline Androscoggin River at Bethel 1 & 19.3 & 2.3 & 17.0 \\
\hline Androscoggin River at Bethel 2 & 16.0 & 0 & 16.0 \\
\hline Penobscot River at Lincoln 1 & 11.9 & 0 & 11.9 \\
\hline Penobscot River at Lincoln 2 & 18.5 & 4.1 & 14.4 \\
\hline Penobscot River at Lincoln 3 & 18.3 & 0 & 18.3 \\
\hline Penobscot River at Lincoln 4 & 13.5 & 0 & 13.5 \\
\hline Penobscot River at Lincoln 5 & 16.4 & 0 & 16.4 \\
\hline Penobscot River at Lincoln 6 & 16.6 & 1.9 & 14.7 \\
\hline Aroostook River at Ashland 1 & 8.8 & 3.1 & 5.7 \\
\hline Aroostook River at Ashland 2 & 16.5 & 1.9 & 14.6 \\
\hline St. John River at Van Buren 1 & 12.4 & 4.3 & 8.1 \\
\hline St. John River at Van Buren 2 & 12.7 & 12.0 & 0.7 \\
\hline St. John River at Van Buren 3 & 12.5 & 0 & 12.5 \\
\hline St. John River at Van Buren 4 & 4.6 & 0 & 4.6 \\
\hline Austin Stream at Bingham 1 & 19.9 & 3.5 & 16.4 \\
\hline Austin Stream at Bingham 2 & 11.2 & 0.5 & 10.7 \\
\hline Saco River at Hiram 1997 & 4.5 & 9.0 & -4.5 \\
\hline Saco River at Hiram 1998 & 10.5 & 7.0 & 3.5 \\
\hline
\end{tabular}


Based on the data collected in this study, the HEC-18 pier-scour equations performed well as envelope equations in Maine (fig. 6, table 10). Twenty-two out of 23 pier-scour depths were overpredicted. The overprediction ranged from $0.7 \mathrm{ft}$ (St. John River at Van Buren, Maine) to $18.3 \mathrm{ft}$ (Penobscot River at Lincoln, Maine) with an average overprediction of $12.0 \mathrm{ft}$. For a high flow at one site (1997 high flow, Saco River at Hiram, Maine), the maximum pier-scour depth was underpredicted by $4.5 \mathrm{ft}$. Pier scour from the 1998 high flow at the Saco River at Hiram, Maine was not underpredicted. The predicted scour for the Saco River site was very sensitive to whether the footing became exposed in the HEC-18 calculations (when the average scour, the maximum scour divided by 2 , brings the river bed below the top of the footing). The footing was not exposed, on average, in 1997 but it was slightly exposed (by $0.25 \mathrm{ft}$ ), on average, in the 1998 calculations. The method of computing average scour in HEC18 may be too simplistic when deciding whether to include scour caused by pier footings.

\section{OBSERVED PIER-SCOUR DEPTHS ASSO- CIATED WITH DEBRIS}

Pier scour associated with debris lodged on a pier was observed at two sites in this study (Saco River at Hiram, Maine; Austin Stream at Bingham, Maine). At both sites, the debris lodged on the piers after a highflow scour measurement was made. No substantial debris was observed on any piers during any high-flow measurements in this study. Surface accumulations of debris are visible during high flows. Sub-surface accumulations can be observed when sounding near a pier.

The maximum pier-scour depth observed at Saco River during low-flow conditions in 1998 was $5.4 \mathrm{ft}$ greater than the high-flow maximum pier-scour depth observed in the spring of 1998. MDOT divers observed various trees and brush lodged on the pier during 1998 low-flow conditions. The location of the maximum pier-scour depth moved from near the nose to approximately halfway down the side of the pier. The maximum pier-scour depth at Austin Stream (pier 1, left pier looking downstream) observed during lowflow conditions in 2000 was $4.6 \mathrm{ft}$ greater than the high-flow pier-scour depth in the spring of 2000. A large amount of trees and brush was visible on the pier during 2000 low-flow conditions (fig. 7). The location of the maximum pier-scour depth did not change appreciably from the location during the high-flow scour measurement. The maximum pier-scour depths associ- ated with the debris at these two sites may have been larger during high flows than during the low flows when the scour was measured. The additional scour associated with debris accumulation at these two sites shows the importance of regular bridge inspections and debris removal.

\section{SUMMARY}

Pier scour can cause the failure of a bridge. Current equations and methods for estimating pier scour at bridges primarily are based on laboratory research. Little field data have been collected to verify the accuracy of these equations for the range of soil conditions, river flow conditions, and bridge designs encountered throughout the United States. The U.S. Geological Survey, in cooperation with the Maine Department of Transportation began a project in 1997 to study pier scour in Maine. The purpose of this report is to describe pier-scour measurements that were made during high flows in Maine from 1997 through 2001 and to compare observed pier scour from these measurements to pier scour predicted by equations in HEC-18, $4^{\text {th }}$ edition, the Federal Highway Administration method of computing bridge scour in the United States.

Pier-scour and related data were collected and analyzed before, during, and after nine high river flows at eight bridges across Maine. Observed maximum pier-scour depths were computed using the concurrent ambient bed level method. Pier scour was observed at all eight measured bridges in this study. Fifteen out of 23 piers measured during a high flow had pier scour ranging from $0.5 \mathrm{ft}$ to $12.0 \mathrm{ft}$ whereas no pier scour was observed at the remaining 8 piers. Observed non-zero bridge scour averaged $4.2 \mathrm{ft}$.

The HEC-18 pier-scour equations performed well as envelope equations for rivers in Maine. Underpredictions are not desirable in an envelope equation. Predicted maximum pier-scour depths were computed using the equations in HEC-18 with velocity and depth data collected during high flows. Twenty-two out of 23 pier-scour depths were overpredicted by $0.7 \mathrm{ft}$ to 18.3 $\mathrm{ft}$, with an average overprediction of $12.0 \mathrm{ft}$. One pierscour depth was underpredicted by $4.5 \mathrm{ft}$. At two bridges in this study, substantial amounts of debris lodged on a pier after high-flow measurements were made at those sites. The scour associated with the debris increased the maximum pier-scour depths by approximately $5 \mathrm{ft}$ in each case. 


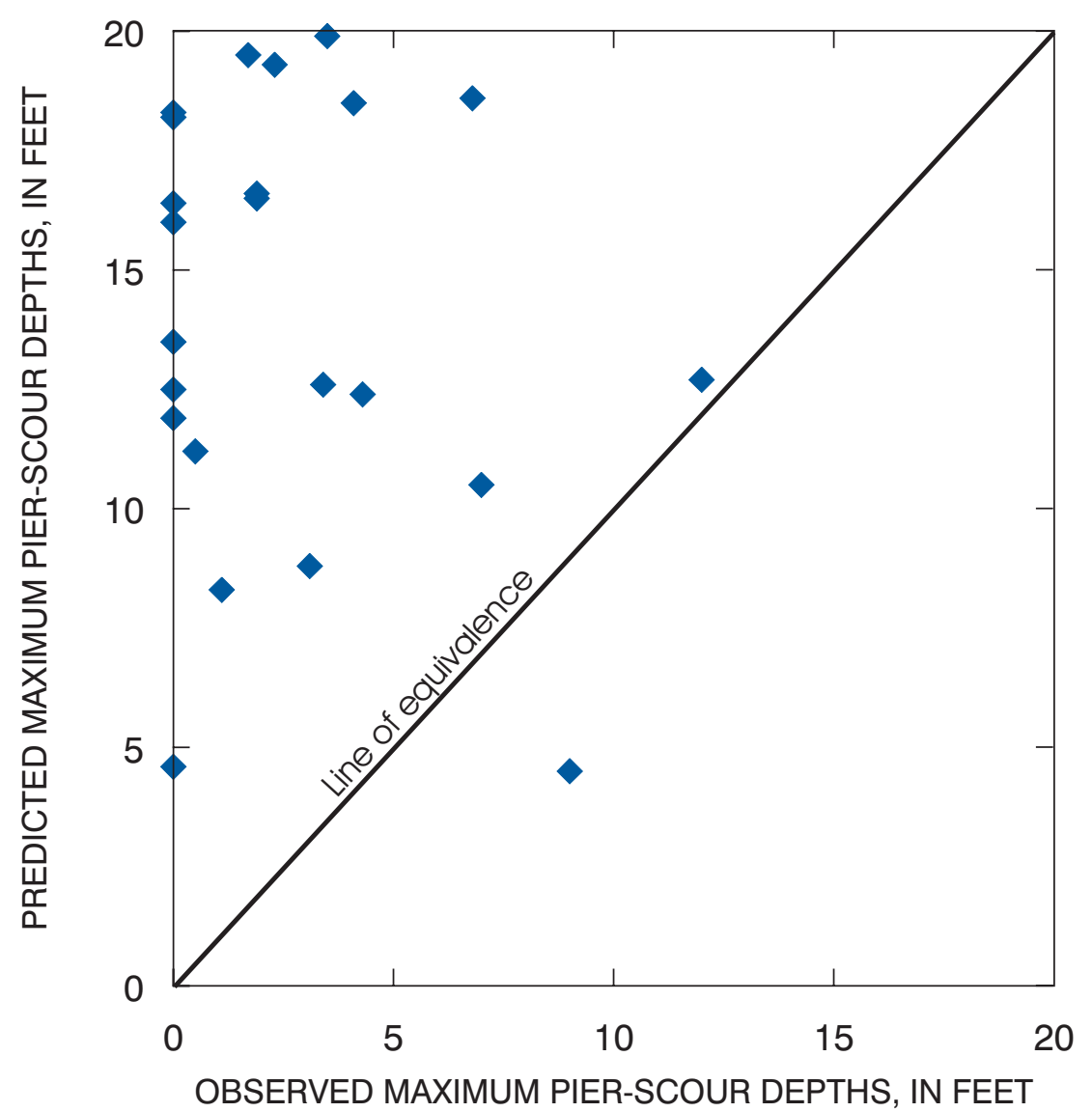

Figure 6. Observed and predicted maximum pier-scour depths.

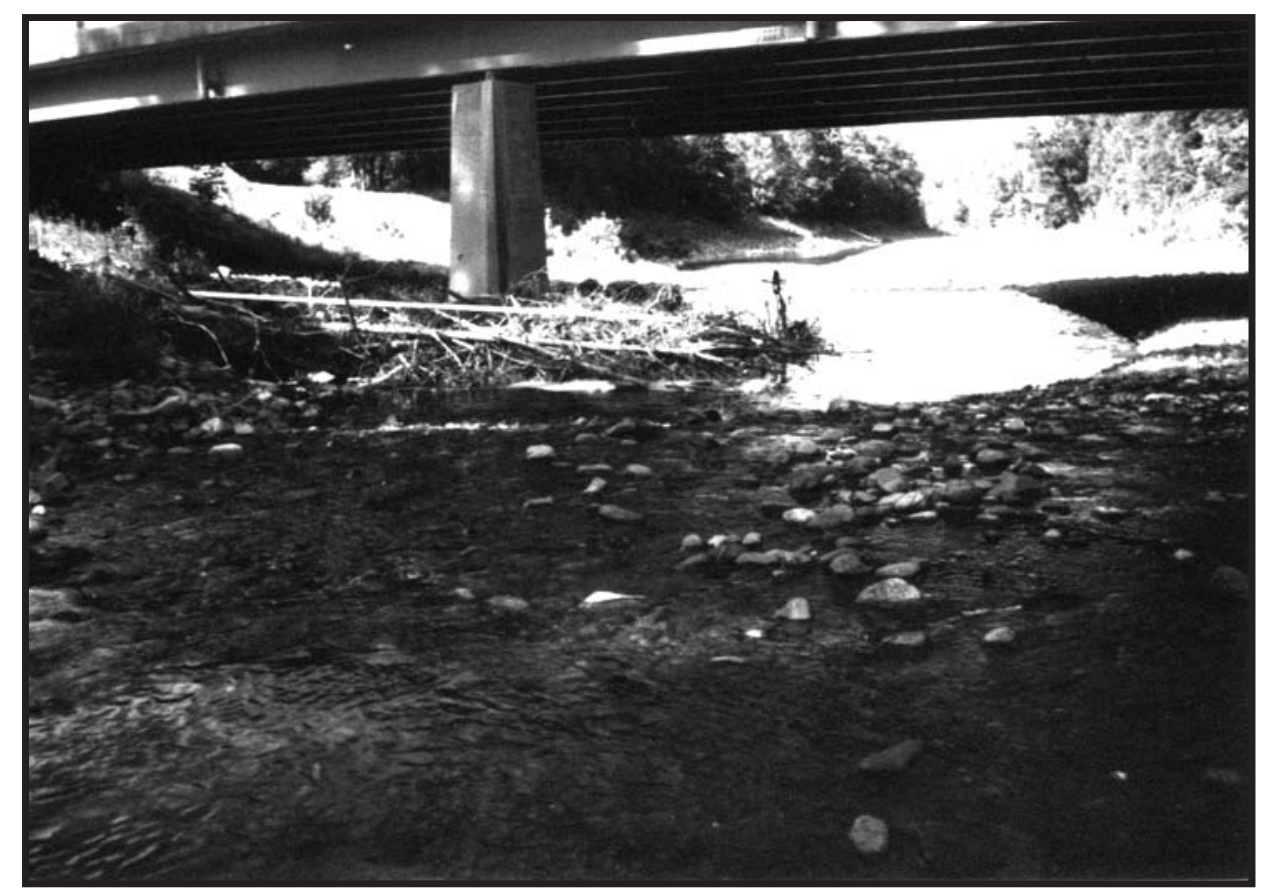

Figure 7. Woody debris accumulation on upstream nose of left (looking downstream) bridge pier at Austin Stream at Bingham, Maine, June 28, 2000. 


\section{REFERENCES CITED}

American Association of State Highway and Transportation Officials, 2001, Standard specifications for transportation materials and methods of sampling and testing (21st ed.): Washington D.C., American Association of State Highway and Transportation Officials.

Ashmore, P.E., Yuzyk, T.R., and Herrington, R., 1988, Bedmaterial sampling in sand-bed streams: Sediment Survey Section, Water Resources Branch, Inland Waters Directorate, Environment Canada, Report IWD-HQWRB-SS-88-4, 83 p.

Hayes, D.C., 1993, Site selection and collection of bridgescour data in Delaware, Maryland, and Virginia: U.S. Geological Survey Water-Resources Investigations Report 93-4017, 23 p.

Hodgkins, G.A., 1999, Estimating the Magnitude of Peak Flows for Streams in Maine for Selected Recurrence Intervals: U.S. Geological Survey Water-Resources Investigations Report 98-4008, 45 p.

International Organization for Standardization, 1977, Liquid flow measurement in open channels-Bed material sampling: International Organization for Standardization4364-1977(E), 13 p. , 1989, Liquid flow measurement in open channels-Sampling and analysis of gravel-bed material: International Organization for Standardization Draft International Standard 9195, 9 p.

Jones, J.S., 1984, Comparison of prediction equations for bridge pier and abutment scour: Transportation Research Record 950, Second Bridge Engineering Conference, Vol. 2, p. 202-209.

Lagasse, P.F., Thompson, P.L., and Sabol, S.A., 1995, Guarding against scour: Civil Engineering, v. 65, no. 6, p. 56-59.

Landers, M.N. and Mueller, D.S., 1993, Reference surfaces for bridge scour depths: Proceedings of the 1993 Conference on Hydraulic Engineering, American Society of Civil Engineers, p. 2075-2080.

Landers, M.N., Mueller, D.S., and Martin, G.R., 1996, Bridge-scour data management system user's manual: U.S. Geological Survey Open-File Report 95-754, 11 p.

Mueller, D.S., 1996, Local scour at bridge piers in nonuniform sediment under dynamic conditions: Dissertation in partial fulfillment of the requirements for the degree of Doctor of Philosophy, Colorado State University, Fort Collins, CO.

Mueller, D.S. and Jones, J.S., 1999, Evaluation of recent field and laboratory research on scour at bridge piers in coarse bed materials, in Richardson, E.V. and Lagasse, P.F. (eds.), Stream stability and scour at highway bridges: Reston, Va., American Society of Civil Engineers Compendium, p. 298-310.

Murillo, J.A., 1987, The scourge of scour: Civil Engineering, v. 57 , no. 7 , p. $66-69$.
Rantz, S.E., and others, 1982, Measurement and computation of streamflow. V. 1, Measurement of stage and discharge: U.S. Geological Survey Water-Supply Paper 2175,284 p.

Richardson, E.V. and Davis, S.R., 2001, Evaluating scour at bridges (4th ed.): U.S. Department of Transportation, Federal Highway Administration Hydraulic Engineering Circular 18, Publication No. FHWA-NHI-01-001.

Yuzyk, T.R., 1986, Bed material sampling in gravel-bed streams: Sediment Survey Section, Water Resources Branch, Inland Waters Directorate, Environment Canada, Report IWD-WRB-HQ-SS-86-7, 74 p. 

District Chief

Maine District

U.S. Geological Survey

Water Resources Division

196 Whitten Road

Augusta, ME 04330 